\title{
GCU
}

Glasgow Caledonian

University

University for the Common Good

\section{Impact of ownership structure and ownership concentration on credit risk of Chinese commercial banks}

\author{
Liu, Yang; Brahma, Sanjukta; Boateng, Agyenim
}

Published in:

International Journal of Managerial Finance

DOI:

10.1108/IJMF-03-2019-0094

Publication date:

2019

Document Version

Author accepted manuscript

Link to publication in ResearchOnline

Citation for published version (Harvard):

Liu, Y, Brahma, S \& Boateng, A 2019, 'Impact of ownership structure and ownership concentration on credit risk of Chinese commercial banks', International Journal of Managerial Finance, vol. 16, no. 2, pp. 253-272. https://doi.org/10.1108/IJMF-03-2019-0094

\section{General rights}

Copyright and moral rights for the publications made accessible in the public portal are retained by the authors and/or other copyright owners and it is a condition of accessing publications that users recognise and abide by the legal requirements associated with these rights.

Take down policy

If you believe that this document breaches copyright please view our takedown policy at https://edshare.gcu.ac.uk/id/eprint/5179 for details of how to contact us. 


\section{International Journal of Managerial F}

\section{Impact of Ownership Structure and Ownership Concentration on Credit Risk of Chinese Commercial Banks}

\begin{tabular}{|r|l|}
\hline Journal: & International Journal of Managerial Finance \\
\hline Manuscript ID & IJMF-03-2019-0094.R1 \\
\hline Manuscript Type: & Research Paper \\
\hline Keywords: & $\begin{array}{l}\text { Credit Risk, Ownership Structure, Ownership Concentration, Herfindahl } \\
\text { Hirchmann Index, Non-Performing Loan Ratio, Loan Loss Provision }\end{array}$ \\
\hline \multicolumn{2}{|l}{} \\
\hline
\end{tabular}

\section{SCHOLARONE \\ Manuscripts}




\section{Introduction}

Prior studies document that performance and risk-taking behaviours of firms are influenced by number of factors including the regulatory regime of particular industry, level of supervision within the firm, and the characteristics of the shareholders (Barry et al, 2011; John et al, 2008, Dong et al, 2014). Samet et al. (2018) contend that market discipline through increased bank regulation and supervision would curb excessive risk-taking propensity of the government owned banks (GOBs). Conversely, GOBs are likely to face political pressure that could lead to channelling of funds to finance projects with high social returns but high risk or to finance preferred groups (Clark et al., 2005 and Shliefer and Vishny, 1994). This argument is supported by grabbing hand theory which states that government owned firms are likely to serve the interests of politicians by appointing government bureaucrats as firm managers (see Shliefer and Vishny, 1994, 1998). State owned banks may be unable to fight this risky government intrusion while the private owned banks are able to resist it and adopt more guarded lending practices (Shirley and Nellis, 1991; Shleifer and Vishny, 1994). In addition, lack of performance incentives and 'soft' budget constraints push state owned banks to take higher 
risk and misallocation of resources (Shirley and Nellis, 1991; Shleifer and Vishny, 1994; Shleifer and Vishny, 1997).

The above theoretical contention appears consistent to some empirical evidences. On one hand, Angkinand and Wihlborg (2010); Iannotta et al (2007), (2013); Jia (2009); Shleifer and Vishny (1997); Sheshinski and Lopez-Calva (2003) and Clark et al. (2005) document that government owned banks (GOBs) have higher credit risk and less prudent lending behaviours. They point out that the GOBs find it difficult to resist government interventions thereby leading to more risk-taking while privately owned banks (POBs) are more guarded in their lending practices and hence have lower credit risks (Shirley and Nellis, 1991; Shleifer and Vishny, 1994). On the other hand, some studies have showed that state-controlled banks take lower risk in Russia (Fungáčová et al. 2013) and higher efficiency in India (Bhattacharyya, Lovell and Sahay 1997) and Turkey (Isik and Hassan 2002). Overall the results are inconclusive and the role of controlling shareholders in credit risk decisions is largely under-researched in emerging markets.

In addition to ownership structure, another significant factor may affect banks' performance and risk taking is ownership concentration ${ }^{1}$. Theoretical literatures have envisaged mixed impact of ownership concentration on firms' performance. Some studies have suggested that concentrated ownership can mitigate free-rider problem and improve firm performance through better supervision of management (Shleifer and Vishny,1986 and Admati et al, 1994). The other line of thinking suggest that concentrated ownership can exacerbate agency problem as dominant shareholders could exercise control and reap personal gain at the expense of minority shareholders (La Porta et al 1999; Shleifer and Vishny, 1997).

In similar vein, empirical studies also documented mixed outcome in relation to ownership concentration and bank performance. Laeven and Levine (2009) showed that banks with more powerful owners have propensity to take higher risks. Haw et. al. (2010) found that concentrated ownership lead to higher insolvency risk and greater return volatility for a sample of listed commercial banks in East Asia and Western Europe. Conversely, Shehzad et al. (2010) showed that volume of NPLs get reduced with ownership concentration of more than $50 \%$. Similarly, Garcia-Marco and Robles-Fernández (2008), found that ownership concentration leads to lower level of risk-taking in Spanish commercial bank and better loan quality, lower asset risk and a lower insolvency risk (Iannotta et al. 2007).

Despite the mixed results and conflicting arguments, prior studies on corporate governance have largely focused on non-financial firms. However, non-financial firms are different from financial firms in terms of transparency, regulation and business strategies (Mehran et al, 2011). Importantly, the few existing banking literatures in Chinese context have focused on the determinants of banks' accounting performance or efficiency (see Berger et al, 2009; Fu and Heffernan, 2009, 2010; Kumbhakar and Wang 2007; Lin and Zhang, 2009; Zhang et al, 2013). Relatively little attention has been given to ownership structure and their implications for bank risk taking behaviour in China. Yet, government participation in business activities through its ownership of firms while maintaining regulatory control may raise agency and political issues with implications for risk taking behaviour (Boateng, Yang and Brahma, 2019). Indeed, government ownership of banks is among the most important institutions in emerging countries and appears pervasive in Chinese banking industry (Boateng, Huang and Kufuor, 2015). It is therefore imperative that we investigate the effects of ownership structure on bank risk-taking

\footnotetext{
${ }^{1}$ Ownership concentration refers to the distribution of the ownership among different institutions and individuals and is related to shareholders' controlling power.
} 
in China. The purpose of this study is twofold: (i) to examine the impact of ownership structure on bank credit risk (ii) to examine the impact of ownership concentration on bank credit risk. Employing a sample of 88 banks in China over the period 2003-2018, we examine the effects of ownership structure on credit risks proxies, namely NPLR and LLPR, utilizing the system GMM regression approach to overcome endogeneity concerns.

The choice of China and Chinese banks appears appropriate setting to investigate this subject for the following reasons. First, Chinese banking sector has undergone significant reforms since 1979 that changed the ownership structure of these banks resulting in the two-tier ownership structure. Given these massive reforms in the Chinese banking sector, this study deepens our understanding on the effectiveness of Chinese banks' corporate governance reforms on managing credit risks, which are measured by non-performing loan ratio (NPLR) and loan loss provision ratio (LLPR). Second, similar to other emerging countries, China is marked by weak institutions and underdeveloped corporate governance system and government ownership of banks appears more pervasive (Du and Boateng, 2015; Singh and Gaur, 2009; Dahya et al., 2003). Du et al (2016) contend that the Chinese government actively intervenes in businesses as shareholder and economic manager to pursue social and political goals rather than maximisation of shareholder wealth which amplifies agency problems. In addition, political connections are ingrained in the institutional framework of several emerging economies with potential consequences on firm performance and risk-taking strategies (Chin et al., 2013; Grossman et al., 2016). These considerations led to the choice of China as an empirical setting for this study.

By way of preview, our results show that POBs tend to take more risk than GOBs. We also found that ownership concentration increases credit risk for POBs but reduce credit risk for GOBs. This study contributes to the literature in the following ways. First, this study contributes to the literature of corporate governance in the banking sector by providing fresh evidence on the impact of both ownership structure and ownership concentration on credit risk. Prior studies either focused on ownership structure (Barry et al., 2011; Forssbæck, 2011; Nichols et al., 2009) or on the degree of ownership concentration (Iannotta et al., 2013; Laeven and Levine, 2009; Sullivan and Spong, 2007). Second, given that emerging markets have restructured the corporate governance system over the past two decades, this study deepens our knowledge on the efficiency of bank boards in emerging markets particularly in the context of the growing Chinese banking sector. Third, this study provides new insight to agency theory by examining the effectiveness of corporate boards in their credit risk decisions, particularly those that are under government ownership and are likely to be influenced by political pressure.

The rest of the paper is structured as follows. Section two presents the institutional background. Section three discusses relevant literature and hypotheses of the study. The fourth section discusses the data collection and sample selection. Section five presents the research methodology and section size shows the main results. The final section summarises the study.

\section{Institutional background}

The Chinese authorities have restructured the Chinese banking sector over the past thirty years with the aim of making the banking sector that was policy-driven, wholly owned and monopolistic into market oriented and competitive institutions. This involved ushering of foreign investors, issuing of shares through the stock market and sell to domestic investors. This led to the creation of numerous classes of banking establishments that functioned in distinct market sectors. The China Banking Regulatory Commission (CBRC) have categorized 
the Chinese banks into wholly state-owned policy banks, large-scale (state-owned) commercial banks, joint stock commercial banks (JSCBs), city commercial banks (CCBs), rural commercial banks (RCBs), locally incorporated foreign banks, and other financial institutions.

Chinese banking sector is dominated by five largest commercial banks (known as Big Five): Agricultural Bank of China (ABC), Bank of China (BOC), China Construction Bank (CCB), Industrial and Commercial Bank of China (ICBC) and the Bank of Communication (BOCOM). In 2003, the Chinese government adopted a partial privatization strategy through which some fractions of the shares of the Big Five were transferred to domestic and foreign institutions. However, the Chinese government retained the ultimate voting control and continued to exercise substantial sway over the administration and lending customs of these banks (Oliver et al. 2014; Dong et al. 2014).

The JSCBs were created fairly recently compared to the SOCBs. Hence the JSCBs are not marred by historical lending practices specifically NPLs. As a result, JSCBs are more open to market conditions. JSCBs finance small and medium enterprises that are disregarded by the Big Five. Some JSCBs are owned by private investors like the China Minsheng Bank and China Zheshang Bank but the bulk is held by the SOEs (Lin and Zhang 2009; Dong et al. 2014).

The urban credit cooperatives (UCCs) were restructured and consolidated into city commercial banks (CCBs). Originally the CCBs were owned by local government to fund local economic development. CCBs were gradually transformed into joint-equity corporations with a diversified ownership including treasuries of local government, SOEs, private investors and foreign investors. In 2005, the CCB was listed on the Hong Kong and Shanghai Banking Corporation and raised $\$ 8$ billion in the initial public offering (IPO). In 2006, the BOC had listed on the Hong Kong Stock Exchange (HKSE) and raised about $\$ 9.7$ billion. ICBC became the world's largest bank by market value in 2007 by being listed on HKSE. The rural credit cooperatives were restructured in 2003, from policy driven rural businesses into market oriented urban ones by forming rural commercial banks (RCBs).

In any corporate governance framework, the largest shareholders act as controlling shareholders and tend to exert substantial control rights by leading in the decision making process. Hence in this study to examine bank risk taking and ownership structure we group the Chinese commercial banks into two types: government owned banks (GOBs) and privately owned banks (POBs).

\section{Hypothesis development}

Barry et al. (2011) argue that agency costs and bank risk-taking may vary depending on the ownership structure. Empirical literatures have reported mixed results on ownership structure and bank risk taking. Theory suggests that dispersed ownership will increase bank risk taking (Galai and Masulis 1976; Jensen and Meckling 1976 and Demsetz and Lehn 1985). (Saunders et al. 1990) was the first empirical study on ownership structure and bank risk-taking. This study reported that managerial stock option increases risk-taking. In similar vein, Sullivan and Spong (2007) show that stock ownership by hired managers is positively linked with bank risk. Other studies reported either a negative relationship or U-shaped relationship between ownership structure and bank risk-taking (Gorton and Rosen 1995; Chen et al. 2009; Anderson and Fraser 2000). 
As mentioned in the previous section, empirical literatures have documented mixed evidences between ownership concentration and bank risk- taking. Bouvatier et al. (2014); Kiruri (2013); Demsetz and Villalonga (2001); Anstoniadis (2010) and Kim et al. (2012) note that majority shareholders (i.e. top five shareholders) influence firms' decision-making and strategy through their voting right. Several empirical literatures have used Herfindahl-Hirchmann Index (HHI) as the measure of ownership concentration ${ }^{2}$ (see Dong et al. 2014; Demsetz and Lehn 1985; Hou et al. 2013). HHI is the sum of the squared ownership of shares of top five shareholders following Margaritis and Psillaki (2010) and Chen et al. (2009). Cao et al. (2011) and Chen et al. (2009) show that top shareholders and their dominance is reflected on bank risk-taking behaviours.

\subsection{Government Owned Banks}

In the context of Chinese commercial banks, the GOBs are characterised by politically connected boards (Boateng et al. 2019) as they generally serve as policy-lending conduits for the government to provide loans to SOEs or government investment (Oliver et al. 2014; Dong et al. 2014). Hence the GOBs may not adopt value maximising strategies. According to China Bank Regulatory Commission (2010), Chinese banks' loans soared to a record RMB 9,590 billion in 2009. In addition, the GOBs get financial and regulatory support from the government (Faccio et al. 2006). This government support also gives confidence to the GOBs to take higher credit risks. Hence, we advance the following hypotheses.

\section{H1: Government ownership of banks in China is positively related to credit risk.}

\subsection{Privately Owned Banks}

In the context of POBs', their management would be more inclined towards lending activities that would increase the banks' wealth as unlike GOBs which tend to pursue social goals. To maximise shareholders' wealth, POBs would hire managers who have significant expertise in the banking sector. In addition, the POBs do not get government guarantees for their risk taking. Moreover, POBs' management are monitored externally and could be subject to takeover in the market for corporate control. Hence managers of POBs would be more pragmatic in its lending decisions (Berglöf and Roland 1998; Sheshinski and Lopez-Calva 2003). Given these arguments we propose the following hypothesis.

\section{H2: Private ownership of bank in China is positively related to credit risk.}

\subsection{Ownership Concentration}

In this study, ownership concentration is measured by Herfindahl Hirchmann Index (HHI), which is the sum of the squared ownership shares of the top five shareholders. Bai et al. (2004), Busta et al. (2014) and Agusman et al. (2014) reported that ownership concentration impacts on organizational structure and decision-making. In emerging market context, the impact of ownership concentration appears severe where these banks are state owned and are politically connected. Prior studies (e.g., La Porta et al. 2002; Sapienza 2006) underscore this point and indicate that GOBs with a higher concentration are usually accompanied by political influences to achieve political and social objectives.

\footnotetext{
${ }^{2}$ Herfindahl-Hirschman Index (HHI) is the sum of the squared ownership shares of the top five shareholders of the bank.
} 
In the context of China, the strategies and operations of government-controlled banks are more likely to be the subject of political intervention and government support (Oliver et al. 2014; Dong et al. 2014). According to agency theory, a higher ownership concentration may easily lead to diversion of resources or credit to curtail credit risk and enhance lending activities (Cornett et al. 2010; Bonin et al. 2005; Fries and Taci 2005; Iannotta et al. 2007; 2013). This view is also supported by the empirical studies of Dong et al. (2014), Hou et al. (2016) and Demsetz and Lehn (1985). In line with these arguments we propose the following hypothesis.

\section{H3a: Ownership concentration is negatively related to credit risk for Chinese GOBs}

Berger et al. (2009), Coffee (2001), Nguyen et al. (2015) and Tipurić et al. (2014) found that POBs with dispersed ownership face poor lending decisions thereby exacerbating the bank's credit risk-taking behaviours. Shehzhad et al. (2010) in similar line documented that dispersed ownership leads to inefficient decision making. In Chinese context, Dong et al. (2014) and Lin and Zhang (2009) state that POBs with concentrated ownership lead to higher credit risk due to fewer political supports, higher profit goals and returns, asymmetrical loan information and less monitoring. The above empirical evidence suggests that concentrated ownership in the hands of private banks will increase credit risk (Berger et al. 2009; Coffee 2001; Tipurić et al. 2014; Agusman et al. 2014). Hence we advance the following hypothesis.

\section{H3b: Ownership concentration (HHI) is positively related to credit risk in Chinese POBs.}

\subsection{Sample and Data Sources}

The data is derived from the records of Chinese Stock Market and Accounting Research Database (CSMAR), China Statistical Yearbook published by the National Bureau of Statistics of China and the Bankscope database provided by Fitch-IBCA (International Bank Credit Analysis Ltd). The initial sample totalled 127 Chinese banks. We imposed several restrictions to derive the final sample. First, only commericial banks, that is, city commercial banks, rural commercial banks and foreign banks are included. Consequently 12 policy banks are excluded because they may have different objectives rather than profitability. Second, 27 banks with missing data such as non-performing loans and other relevant data are excluded. The imposition of these restrictions led to the final usable sample of 88 banks and 1194 observations (i.e. 301 state-owned banks and 893 privately owned banks), covering the sixteen-year period from 2003 to 2018 . The data relating to the ownership structure of the banks were hand collected from the annual reports obtained from official website of the banks.

\subsection{Measures of bank-risk taking}

We employ two different risk measures as dependent variables and proxies for credit risk, namely, non-performing loan ratio (NPLR) and loan loss provision ratio (LLPR). NPLR is the sum of total loans and leases over the past 90 days or more and non-accrual loans, divided by total amount of outstanding loans (Berger et al. 2009; Ghosh 2015). Following Lee and Chih (2013), Elnahass et al. (2014), we estimate the LLPR as loan loss provision (LLP) divided by net interest revenue (NIR).

\subsection{Measures of ownership concentration and ownership structure}

This study has included two measures of ownership: ownership concentration and ownership structure. Both these measures include both the owners' motivations and the authority of 
shareholders. As mentioned earlier, ownership concentration is measured by HHI. This is measured as the sum of the squared ownership shares of the five largest shareholders of the banks. HHI is a robust measure and has been used extensively in other empirical studies to examine ownership concentration (Kim et al. 2012; Dong et al. 2014; Hou et al. 2013; Demsetz and Lehn 1985). To test ownership structure, we follow Agusman et al. (2014) and divide the sample into two types of banks (i.e. GOBs and POBs) to measure the effect of government intervention and credit decisions.

\subsection{Control Variables}

Following Garcia-Herrero et al. (2009), and Boateng et al. (2019) we control the macroeconomic and bank-specific variables, namely, CEO total compensation (CEO_TC), gross domestic product rate (GDPR), inflation rate (INFR), unemployed rate (UNEMP), bank leverage ratio (LEVR) and bank size (SIZE). Fries and Taci (2005) showed that gross domestic product (GDP) is an indicator of economic performance and in turn plays a role in bank's lending policies. Ghosh (2015) advanced that inflation rate has negative impact on the real income of borrowers. The macroeconomic variables are closely related to risk-taking behaviours and banks' credit decisions (Grigorian and Manole 2002; Fries and Taci 2005; Ghosh 2015). Fu and Hefferman (2009) documented that unemployment rate increases default risk and thereby leads to rise in NPLs and loan loss reserves.

Luo and Ying (2014) and Leuz and Oberholzer-Gee (2006) observed that bank size is positively related to loan portfolio and default rates. In similar vein, Sapienza (2006) documented that bank size may also influence the ability to take and absorb risk. Jensen and Murphy (1990) reported that CEO compensation is positively linked to firm risk taking. Hence in this study we have controlled total compensation. Table 1 presents the definition of the variables.

\section{Insert Table 1}

The summary statistics of the variables are shown in table 2 . In the context of the dependent variables the mean NPLR is 2.35 and the mean LLPR is 0.72 . The mean coefficient of ownership concentration is 0.1027 . This result is similar to Dong et al. (2014). The mean value of GOVBANK is a higher $73.53 \%$, indicating that state-owned shares are very high in the Chinese GOBs, and also implying that the GOBs have a higher ownership concentration and shareholder controlling rights. This means that the Chinese government intervention would have significant impact on the lending activities of GOBs. On the other hand, the mean value of private ownership of banks (POBs) is $18.79 \%$ and that is significantly lower in comparison to GOBs.

Insert Table 2

\subsection{Correlation matrix}

Table 3 reports the correlation matrix of dependent and independent variables. A correlation of 0.7 in absolute value or higher may indicate multicollinearity. All the variables have correlation coefficient that is lower than 0.7 . This study has also reported the variance inflation factor (VIF) and the results suggest that all the VIFs are well below 4.0 and hence multicollinearity is absent.

Insert Table 3 


\section{Empirical approach and model}

To examine the impact of ownership concentration and ownership structure on bank risk-taking we apply a model in a dynamic framework as adopted by several empirical studies of corporate governance and bank risk-taking (see Dong et al. 2014). Specifically, we have applied twostep system generalized method of moments (SGMM) approach by Arellano and Bover (1995) and Blundell and Bond (1998) as our main estimation technique to estimate equations 1 and 2 following Wintoki, Linck, and Netter (2012) and Dong et al. (2014). This method treats all the explanatory variables as endogenous and orthogonally use the past values as their corresponding instruments. The reliability of SGMM has been checked using Hansen's test for instrument validity. The purpose of using the two-step system SGMM is to account for endogeneity that may affect the variables. The SGMM estimator use internal instruments that are obtainable within the panel itself (Blundell \& Bond 1998). Flannery and Hankins (2013) advanced that the SGMM is the best-performing estimator within common data features that are present in our dataset: (i) short panel; (ii) endogenous explanatory variables; and (iii) dynamic panel bias. The models are specified as follows:

$$
\begin{aligned}
& \text { CRisk }_{i t}=\alpha+\beta_{1} \text { CRisk }_{i t-1}+\beta_{2} \text { GOVBANK }_{i t}+\beta_{3} \text { HHI }_{i t}+\text { SControls }_{i t}+\varepsilon_{i t} \\
& \text { CRisk }_{i t}=\alpha+\beta_{1} \text { CRisk }_{i t-1}+\beta_{2} \text { PRIBANK }_{i t}+\beta_{3} \text { HHI }_{i t}+\delta \text { Controls }_{i t}+\varepsilon_{i t}
\end{aligned}
$$

In equations 1 and 2, subscripts $i$ denote the Chinese banks and $t$ is the time period. The coefficients $\beta j$ are the parameters to be estimated and $\varepsilon$ represent the disturbance term. CRisk represents the two measures of credit risks that are applied in this study, which are nonperforming loan ratio (NPLR) and loan loss provision ratio (LLPR). The set of explanatory variables: GOVBANK, PRIBANK and HHI represent the Chinese GOBs, POBs and degree of ownership concentration respectively. Following La Porta et al. (2002) and Luo and Ying (2014), the independent variables GOVBANK represents the banks where the state-owned share proportion is more than $50 \%$ and PRIBANK represents privately owned banks where more than $50 \%$ of the controlling shareholders are private entities (including foreign legal person) or individuals. The HHI equals the sum of the squared ownership shares of the five largest shareholders of the bank (Demsetz and Lehn, 1985; Hou et al. 2013). The higher the HHI, higher is the ownership concentration. The control variables are macroeconomic variables: gross domestic product rate (GDPR), unemployment rate (UNEMP), inflation rate (INFR) and bank characteristics variables: bank size (SIZE) and bank leverage ratio (LEVR).

\section{Results and Discussions}

\subsection{Ownership structure and credit risk}

Table 4 reports our regression results using two dependent variables, namely, NPLR and LLPR as proxies for credit risk. Our results suggest that government owned banks as shown in model 2 has coefficient which is positive and significant at $1 \%$ indicating that government ownership increases bank credit risk. The results provide support the hypothesis $\mathrm{H} 1$. The results may be explained by the fact that GOBs are characterised by politically connection thereby increasing credit risk as loans may be channelled to SOEs for social objectives instead of commercial activities making it difficult for SOEs to repay the loans. The findings appear consistent with empirical studies by Boateng et al. (2019), Oliver et al. (2014) and Dong et al. (2014). With 
regard to the POBs, the results in table 4 show that credit risk measured by both NPLR and LLPR (models 3 and 4) exhibit a positive and significant relationship with privately owned banks. Hypothesis 2 is therefore not supported. The results appear surprising in that privatelyowned banks tend to be more efficient diligent in assessing credit risk associated with firms before granting loans but this appears not be the case. Perhaps, the results may be due to poor institutions and weak monitoring thereby increasing credit risk.

\subsection{Ownership concentration and credit risk}

Regarding the ownership concentration measured by HHI, the results reported in Table 4 indicate that the coefficient for GOBs in models 5 and 6 is negative and significant at $1 \%$ level. The results suggest that ownership concentrated in the hands of government reduce credit risk measured by both NPLR and LLPR. The results provide support for hypothesis H3a. The results may be explained by the fact that government monitoring may be more effective when share ownership is concentrated in the hands of government thereby reducing credit risk. The results are consistent with empirical evidences by Shehzad et. al. (2010) and Shleifer and Vishny (1986), that concentrated ownership boosts effectiveness of corporate governance.

For POBs, ownership concentration is positive and significant for both measures of credit risk in models 7 and 8 . Hypothesis $\mathrm{H} 3 \mathrm{~b}$ is therefore supported. The results suggest that ownership concentrated in the hands of private banks exacerbate bank credit risk-taking behaviours. This may be due to poor monitoring as private banks may not be able to attract directors with high level of skills and experience to serve on the board compared to government owned banks thereby weakening the monitoring role and increasing credit risk. This result is consistent with the studies by Berger et. al. (2009); Coffee (2001); Tipurić et. al. (2014) and Agusman et. al. (2014).

Regarding control variables, our regression results indicate that the coefficients for GDP and unemployment to have a positive and significant effect on credit risk while inflation rate, bank size and leverage are negatively related to credit risk.

\section{(Insert Table 4 here)}

\subsection{Interaction of ownership structure and ownership concentration on credit risk}

We further analyse the effect of ownership concentration on credit risk by examining the effects of interaction of ownership concentration and ownership type (HHI*GOVBANK and HHI*PRIBANK). As Table 5 shows the coefficient of interaction variable (HHI*GOVBANK) is negative and significant at $1 \%$ for both measures of credit risk, NPLR and LLPR. These results indicate that level of ownership concentration interacts with ownership type to improve corporate governance and lending practices and consequently reduce credit risk. Therefore, ownership concentration and ownership type matter for credit risks. The appear consistent with the studies by Agusman et al. (2014) and Iannota et al. (2007). The interaction term of HHI*PRIBANK is positive and significant at $1 \%$ for both measures of credit risk. These results corroborate our findings in table 4 that block holders in POBs appear to weaken the monitoring role of the board and exacerbate credit risks. 


\subsection{Robustness checks}

The financial crisis in 2009 affect the lending and risk-taking activities of the banks worldwide. To rule out that the financial crisis from 2007 to 2009 is not driving our results, we run further regression analysis excluding the period of financial crisis, and use the following sample periods (2003-2006 and 2010-2014). Our results remain similar to our main results reported in Table 4.

\section{(Insert Table 5 here)}

\section{Conclusion}

This study investigates the effects of ownership structure and ownership concentration and further investigates the effects of interaction between ownership structure and ownership concentration on credit risk of Chinese banks from 2003-2018. Despite a number of studies investigating the influence of ownership structure, virtually, relatively few studies have examined how both ownership type, ownership concentration and the interaction between the two, affect credit risk measured by both NPLR and LLPR. Previous studies by Dong et al. (2014) on China and Barry et al. (2011) on European commercial banks have looked into firm risk-taking measured primarily by z-score. While z-score is a measure of ex-ante probability of default, NPLR and LLPR are direct ex-post measures of credit risk (Srairi 2013). A high value of NPLR and LLPR will result in losses for the bank and hence they are direct measures of credit risk (Delis and Kouretas 2011). In this study, we take up this issue by extending prior research on the relationship between ownership structure and direct measures of credit risk in an emerging market environment where corporate governance systems are weak. Employing a panel data approach and SGMM to mitigate the endogeneity problem, this study reports a number of interesting findings.

First, our results suggest that ownership type (both government and private ownership) exert positive and significant impact on credit risk. An important policy implication of this study is that Chinese government should introduce more stringent regulations on lending policies of the banks. Lastly, our result also shows that an increase in ownership concentration in POBs weakens monitoring role of the board while concentration in the hands of government strengthens the bank credit monitoring. The results imply that government banks appear to be effective monitors compared to private owned banks. Despite the contribution of this study regarding the effect of ownership structure, ownership concentration and their interaction on credit risk, further research is warranted. Future research should conduct a comparative study of these relationships by undertaking a cross-country study.

\section{References}

Acrey, J. C., McCumber, W. R., and Nguyen, T. H. T. (2011), "CEO incentives and bank risk”, Journal of Economics and Business, Vol. 63 No. 5, pp. 456-471.

Admati, A. R., Pfleiderer, P., and Zechner, J. (1994), "Large shareholder activism, risk sharing, and financial market equilibrium", Journal of Political Economy, Vol. 102 No. 6, pp.10971130 . 
Aebi, V., Sabato, G., and Schmid, M. (2012), "Risk management, corporate governance, and bank performance in the financial crisis", Journal of Banking \& Finance, Vol. 36 No.12, pp. 3213-3226.

Aghion, P. and Tirole, J. (1997), "Formal and real authority in organizations", Journal of political economy, Vol. 105 No.1, pp.1-29.

Agusman, A., Cullen, G.S., Gasbarro, D., Monroe, G.S. and Zumwalt, J.K. (2014), "Government intervention, bank ownership and risk-taking during the Indonesian financial crisis", Pacific-Basin Finance Journal, Vol. 30, pp.114-131.

Amihud, Y. and Lev, B. (1981), "Risk reduction as a managerial motive for conglomerate mergers", The bell journal of economics, pp.605-617.

Anderson, R.C. and Fraser, D.R. (2000), "Corporate control, bank risk taking, and the health of the banking industry", Journal of Banking and Finance, Vol. 24 No.8, pp.1383-1398.

Angkinand, A. and Wihlborg, C. (2010), "Deposit insurance coverage, ownership, and banks' risk-taking in emerging markets", Journal of International Money and Finance, Vol. 29 No. 2, pp.252-274.

Antoniadis, I., Lazarides, T. and Sarrianides, N. (2010), "Ownership and performance in the Greek banking sector", in International Conference on Applied Economics, Vol. 3 No. 4, pp. 11-21.

Arellano, M. and Bover, O. (1995), "Another look at the instrumental variable estimation of error-components models", Journal of econometrics, Vol. 68 No.1, pp.29-51.

Bai, C.E., Liu, Q., Lu, J., Song, F.M. and Zhang, J. (2004), "Corporate governance and market valuation in China", Journal of comparative economics, Vol. 32 No.4, pp.599-616.

Barry, T.A., Lepetit, L. and Tarazi, A. (2011), "Ownership structure and risk in publicly held and privately owned banks", Journal of Banking and Finance, Vol. 35 No.5, pp.1327-1340.

Barth, J.R., Lin, C., Lin, P. and Song, F.M. (2009), "Corruption in bank lending to firms: Crosscountry micro evidence on the beneficial role of competition and information sharing", Journal of Financial Economics, Vol.91 No.3, pp.361-388.

Berger, A.N., Hasan, I. and Zhou, M. (2009), "Bank ownership and efficiency in China: What will happen in the world's largest nation?", Journal of Banking \& Finance, Vol. 33 No.1, pp.113-130.

Berglof, E. and Roland, G. (1998), "Soft budget constraints and banking in transition economies", Journal of Comparative Economics, Vol. 26 No.1, pp.18-40.

Bhattacharyya, A., Lovell, C.K. and Sahay, P. (1997), "The impact of liberalization on the productive efficiency of Indian commercial banks" European Journal of operational research, Vol. 98 No.2, pp.332-345. 
Black, F. and Scholes, M. (1973), "The pricing of options and corporate liabilities", Journal of political economy, Vol. 81 No. 3, pp.637-654.

Blundell, R. and Bond, S. (1998), "Initial conditions and moment restrictions in dynamic panel data models", Journal of econometrics, Vol. 87 No.1, pp.115-143.

Boateng, A., Huang, W. and Kufuor, N.K. (2015), "Commercial bank ownership and performance in China”, Applied Economics, Vol. 47 No.49, pp.5320-5336.

Boateng, A., Liu, Y. and Brahma, S. (2019), "Politically connected boards, ownership structure and credit risk: Evidence from Chinese commercial banks", Research in International Business and Finance, Vol. 47, pp.162-173.

Bonin, J.P., Hasan, I. and Wachtel, P. (2005), "Bank performance, efficiency and ownership in transition countries", Journal of banking and finance, Vol. 29 No.1, pp.31-53.

Borisova, G., Brockman, P., Salas, J.M. and Zagorchev, A. (2012), “Government ownership and corporate governance: Evidence from the EU', Journal of Banking \& Finance, Vol. 36 No. 11, pp.2917-2934.

Bouvatier, V., Lepetit, L. and Strobel, F. (2014), "Bank income smoothing, ownership concentration and the regulatory environment", Journal of Banking \& Finance, Vol. 41, pp.253-270.

Burkhart, M., Gromb, D. and Panunzi, F. (1997), "Large shareholders, monitoring, and the value of the firm", Quarterly Journal of Economics, Vol. 112 No. 3, pp.693-728.

Busta, I., Sinani, E. and Thomsen, S. (2014), "Ownership concentration and market value of European banks", Journal of Management and Governance, Vol. 18 No.1, pp.159-183.

Cao, J., Pan, X. and Tian, G. (2011), "Disproportional ownership structure and payperformance relationship: evidence from China's listed firms", Journal of Corporate Finance, Vol. 17 No. 3, pp.541-554.

Chen, C.H. and Al-Najjar, B. (2012), "The determinants of board size and independence: Evidence from China", International Business Review, Vol. 21 No. 5, pp.831-846.

Chen, Y., Guo, R.J. and Huang, R.L. (2009), "Two stages credit evaluation in bank loan appraisal”, Economic Modelling, Vol. 26 No.1, pp.63-70.

Chin, M. K., Hambrick, D. C., and Treviño, L. K. (2013), "Political ideologies of CEOs: The influence of executives' values on corporate social responsibility", Administrative Science Quarterly, Vol. 58 No. 2, pp.197-232.

Clarke, G. R.G., Cull, R., and Shirley, M.M. (2005), "Bank privatization in developing countries: A summary of lessons and findings", Journal of Banking and Finance, Vol. 29, pp.1905-1930.

Coffee Jr, J.C. (2001), "The rise of dispersed ownership: The roles of law and the state in the separation of ownership and control", Yale Lj, Vol. 111, p.1. 
Coles, J.L., Daniel, N.D. and Naveen, L. (2008), “Boards: Does one size fit all?”, Journal of financial economics, Vol. 87 No. 2, pp.329-356.

Cornett, M.M., Guo, L., Khaksari, S. and Tehranian, H. (2010), “The impact of state ownership on performance differences in privately-owned versus state-owned banks: An international comparison", Journal of Financial Intermediation, Vol. 19 No. 1, pp.74-94.

Dahya, J., Karbhari, Y., Xiao, J. Z., and Yang, M. (2003), "The usefulness of the supervisory board report in China", Corporate governance: An international review, Vol. 11 No. 4, pp.308321.

De Bondt, G.J. (1999), "Banks and monetary transmission in Europe: empirical evidence", Banca Nazionale del Lavoro Quarterly Review, Vol. 52 No. 209, p.149.

Delis, M.D. and Kouretas, G.P. (2011), "Interest rates and bank risk-taking”, Journal of Banking and Finance, Vol. 35 No. 4, pp.840-855.

Demsetz, H. and Lehn, K., (1985), "The structure of corporate ownership: Causes and consequences", Journal of political economy, Vol. 93 No. 6, pp.1155-1177.

Demsetz, H. and Villalonga, B. (2001), “Ownership structure and corporate performance", Journal of corporate finance, Vol. 7 No. 3, pp.209-233.

Diamond, D.W. and Rajan, R.G. (2009), "The credit crisis: Conjectures about causes and remedies”, American Economic Review, Vol. 99 No.2, pp.606-10.

Dong, Y., Meng, C., Firth, M. and Hou, W. (2014), “Ownership structure and risk-taking: Comparative evidence from private and state-controlled banks in China", International Review of Financial Analysis, Vol. 36, pp.120-130.

Du, M., \& Boateng, A. (2015), "State ownership, institutional effects and value creation in cross-border mergers \& acquisitions by Chinese firms", International Business Review, Vol. 24, No. 3, pp. 430-442.

Du, M., Boateng, A., and Newton, D. (2016), "The impact of state ownership, formal institutions and resource seeking on acquirers' returns of Chinese M\&A", Review of Quantitative Finance and Accounting, Vol. 47 No.1, pp.159-178.

Elnahass, M., Izzeldin, M. and Abdelsalam, O. (2014), "Loan loss provisions, bank valuations and discretion: A comparative study between conventional and Islamic banks", Journal of Economic Behaviour \& Organization, Vol. 103, pp. S160-S173.

Faccio, M. (2006), "Politically connected firms", American economic review, Vol. 96 No. 1, pp.369-386.

Flannery, M.J. and Hankins, K.W. (2013), "Estimating dynamic panel models in corporate finance", Journal of Corporate Finance, Vol. 19, pp.1-19. 
Fries, S. and Taci, A. (2005), "Cost efficiency of banks in transition: Evidence from 289 banks in 15 post-communist countries", Journal of Banking and Finance, Vol. 29 No. 1, pp.55-81.

Fosu, S. (2014), "Credit information, consolidation and credit market performance: Bank-level evidence from developing countries", International Review of Financial Analysis, Vol. 32, pp.23-36.

Forssbæck, J. (2011), “Owership structure, market discipline, and banks' risk-taking incentives under deposit insurance”, Journal of Banking and Finance, Vol. 351 No.10, pp.2666-2678.

$\mathrm{Fu}, \mathrm{X} . \mathrm{M}$. and Heffernan, S. (2009), "The effects of reform on China's bank structure and performance", Journal of Banking \& Finance, Vol. 33 No.1, pp.39-52.

Fungáčová, Z., Herrala, R. and Weill, L. (2013), "The influence of bank ownership on credit supply: Evidence from the recent financial crisis", Emerging markets review, Vol. 15, pp.136147.

Galai, D. and Masulis, R.W. (1976), "The option pricing model and the risk factor of stock", Journal of Financial Economics, Vol. 3 No.1-2, pp.53-81.

Gambacorta, L (2005), "Inside the bank lending channel", European Economic Review, Vol. 49 No.7, pp.1737-1759.

García-Herrero, A., Gavilá, S. and Santabárbara, D. (2009), "What explains the low profitability of Chinese banks?", Journal of Banking \& Finance, Vol. 33 No. 11, pp.20802092.

Gambacorta, L. (2005), "Inside the bank lending channel", European Economic Review, Vol. 49 No. 7, pp.1737-1759.

Ghosh, A. (2015), "Banking-industry specific and regional economic determinants of nonperforming loans: Evidence from US states", Journal of Financial Stability, Vol. 20, pp.93104.

Gorton, G. and Rosen, R. (1995), "Corporate control, portfolio choice, and the decline of banking”, The Journal of Finance, Vol. 50 No. 5, pp.1377-1420.

Griffith, J.M., Fogelberg, L. and Weeks, H.S. (2002), "CEO ownership, corporate control, and bank performance", Journal of Economics and Finance, Vol. 26 No. 2, pp.170-183.

Grigorian, D.A. and Manole, V. (2002), Determinants of commercial bank performance in transition: An application of data envelopment analysis. The World Bank.

Grosman, A., Wright, M., and Okhmatovskiy, I. (2016), "State control and corporate governance in transition economies: 25 years on from 1989", Corporate Governance, Vol. 24 No. 3, pp.200-221.

Gul, F.A., Kim, J.B. and Qiu, A.A. (2010), “Ownership concentration, foreign shareholding, audit quality, and stock price synchronicity: Evidence from China", Journal of Financial Economics, Vol. 95 No. 3, pp.425-442. 
Hauner, D. (2008), "Credit to government and banking sector performance", Journal of Banking and Finance, Vol. 32 No. 8, pp.1499-1507.

Haw, I.M., Ho, S.S., Hu, B. and Wu, D. (2010), "Concentrated control, institutions, and banking sector: An international study", Journal of Banking \& Finance, Vol. 34 No. 3, pp.485497.

Hirshleifer, D. and Thakor, A.V. (1992), "Managerial conservatism, project choice, and debt", The Review of Financial Studies, Vol. 5 No. 3, pp.437-470.

Hou, W., Lee, E., Stathopoulos, K. and Tong, Z. (2016), "Executive compensation and the split share structure reform in China", The European Journal of Finance, Vol. 22 No. 4-6, pp.506528.

Iannotta, G., Nocera, G. and Sironi, A. (2007), "Ownership structure, risk and performance in the European banking industry", Journal of Banking and Finance, Vol. 31 No. 7, pp.21272149.

Isik, I. and Hassan, M.K. (2002), "Technical, scale and allocative efficiencies of Turkish banking industry", Journal of Banking \& Finance, Vol. 26 No. 4, pp.719-766.

Jensen, M.C. and Murphy, K.J. (1990), "Performance pay and top-management incentives", Journal of political economy, Vol. 98 No. 2, pp.225-264.

Jensen, M.C. and Meckling, W.H. (1976), "Theory of the firm: Managerial behavior, agency costs and ownership structure", Journal of financial economics, Vol. 3 No.4, pp.305-360.

Jia, C. (2009), "The effect of ownership on the prudential behavior of banks-The case of China", Journal of Banking \& Finance, Vol. 33 No. 1, pp.77-87.

John, K., Litov, L. and Yeung, B. (2008), “Corporate governance and risk-taking”, The Journal of Finance, Vol. 63 No. 4, pp.1679-1728.

Kim, P.K., Rasiah, D. and Tasnim, R.B. (2012), “A review of corporate governance: ownership structure of domestic-owned banks in term of government connected ownership, and foreign ownership of commercial banks in Malaysia”, Journal of organizational management studies, 2012, p.1.

Kirkpatrick, G. (2009), "The corporate governance lessons from the financial crisis", $O E C D$ Journal: Financial Market Trends, Vol. 1, pp.61-87.

Kiruri, R.M. (2013), "The effects of ownership structure on bank profitability in Kenya", European Journal of Management Sciences and Economics, Vol. 1 No. 2, pp.116-127.

Kumbhakar, S., and Wang, D. (2007), "Economic reforms, efficiency and productivity in Chinese banking”, Journal of Regulatory Economics, Vol. 32, pp.105-129.

La Porta, R., Lopez-de-Silanes, F. and Shleifer, A. (1999), "Corporate ownership around the world”, The Journal of Finance, Vol. 54 No. 2, pp.471-517. 
La Porta, R., Lopez-de-Silanes, F. and Shleifer, A. (2002), "Government ownership of banks", The Journal of Finance, Vol. 57 No. 1, pp.265-301.

La Porta, R., Lopez-de-Silanes, F., Shleifer, A. and Vishny, R.W. (1997), "Legal determinants of external finance", The Journal of Finance, Vol. 52 No. 3, pp.1131-1150.

Laeven, L. and Levine, R. (2009), "Bank governance, regulation and risk taking", Journal of Financial Economics, Vol. 93 No. 2, pp.259-275.

Lee, T.H. and Chih, S.H. (2013), "Does financial regulation enhance or impede the efficiency of China's listed commercial banks? A dynamic perspective", Emerging Markets Finance and Trade, Vol. 49 (sup4), pp.132-149.

Leung, N.W. and Cheng, M.A. (2013), "Corporate governance and firm value: Evidence from Chinese state-controlled listed firms", China Journal of Accounting Research, Vol. 6 No. 2, pp.89-112.

Leuz, C. and Oberholzer-Gee, F. (2006), "Political relationships, global financing, and corporate transparency: Evidence from Indonesia", Journal of financial economics, Vol.81 No. 2, pp.411-439.

Lin, X. and Zhang, Y. (2009), "Bank ownership reform and bank performance in China", Journal of Banking \& Finance, Vol. 33 No. 1, pp.20-29.

Luo, D. and Ying, Q. (2014), "Political connections and bank lines of credit", Emerging Markets Finance and Trade, Vol. 50 (sup3), pp.5-21.

Margaritis, D. and Psillaki, M. (2010), "Capital structure, equity ownership and firm performance", Journal of banking \& finance, Vol. 34 No. 3, pp.621-632.

Mehran, H., Morrison, A., \& Shapiro, J. (2011), "Corporate governance and banks:What have we learned from the financial crisis?" Federal Reserve Bank of New York. (Staff Report No. $502)$.

Merton, R.C. (1974), "On the pricing of corporate debt: The risk structure of interest rates", The Journal of finance, Vol. 29 No. 2, pp.449-470.

Nguyen, T., Locke, S. and Reddy, K. (2015), "Ownership concentration and corporate performance from a dynamic perspective: Does national governance quality matter?", International Review of Financial Analysis, Vol. 41, pp.148-161.

Nguyen, V.H.T. and Boateng, A. (2015), "An analysis of involuntary excess reserves, monetary policy and risk-taking behaviour of Chinese banks", International Review of Financial Analysis, Vol. 37, pp.63-72.

Nichols, D., Wahlen, J., and Wieland, M. (2009), "Publicly-traded versus privately-held: implications for conditional conservatism in bank accounting", Review of Accounting Studies, Vol. 14, pp.88-122. 
Oliver, J., Qu, W. and Wise, V. (2014), "Corporate governance: a discussion on minority shareholder protection in China", International Journal of Economics and Finance, Vol. 6 No. 3, pp.111-119.

Pathan, S. (2009), "Strong boards, CEO power and bank risk-taking", Journal of Banking \& Finance, Vol. 33 No. 7, pp.1340-1350.

Samet, A., Boubakri, N. and Boubaker, S. (2018), "Does public-private status affect bank risk taking? Worldwide evidence", Journal of International Financial Markets, Institutions and Money, Vol. 53, pp.287-306.

Sapienza, P. (2006), "The Effects of Government Ownership on Bank Lending”, Journal of Financial Economics. World Bank Publications, pp.259-286.

Saunders, A., Strock, E. and Travlos, N.G. (1990), “Ownership structure, deregulation, and bank risk taking”, the Journal of Finance, Vol. 45 No. 2, pp.643-654.

Shehzad, C.T., de Haan, J. and Scholtens, B. (2010), "The impact of bank ownership concentration on impaired loans and capital adequacy", Journal of Banking and Finance, Vol. 34 No. 2, pp.399-408.

Sheshinski, E. and López-Calva, L.F. (2003), "Privatization and its benefits: theory and evidence", CESifo Economic Studies, Vol. 49 No. 3, pp.429-459.

Shirley, M., and Nellis, J. (1991), "Public enterprise reform. The lessons of experience", World Bank, Economic development Institute, Washington. DC.

Shleifer, A. and Vishny, R.W. (1986), "Large shareholders and corporate control", Journal of political economy, Vol. 94 No. 3, Part 1, pp.461-488.

Shleifer, A. (1998), "State versus private ownership", Journal of Economics Perspectives, Vol. 12 No. 4, pp.133-50

Shleifer, A., and Vishny, R. (1994), "Politicians and firms", Quarterly Journal of Economics, Vol. 109 No. 4, pp.995-1025.

Shleifer, A. and Vishny, R.W. (1997), "A survey of corporate governance”, The journal of finance, Vol. 52 No. 2, pp.737-783.

Singh, D. A., and Gaur, A. S. (2009), "Business group affiliation, firm governance, and firm performance: Evidence from China and India", Corporate Governance: An International Review, Vol.17 No.4, pp. 411-425.

Srairi, S. (2013), "Ownership structure and risk-taking behaviour in conventional and Islamic banks: Evidence for MENA countries”, Borsa Istanbul Review, Vol. 13 No. 4, pp.115-127.

Stiglitz, J. E. (1999), "Wither reform? Ten years of transition", Keynote address, Annual Bank Conference on Development Economics. The World Bank. 
Sullivan, R.J. and Spong, K.R. (2007), "Manager wealth concentration, ownership structure, and risk in commercial banks", Journal of Financial Intermediation, Vol. 16 No. 2, pp.229248.

Tipurić, D., Katarina, D. and Delić, M. (2014), "Measuring the quality of corporate governance-a review of corporate governance indices", European Journal of Economics and Management, Vol. 1 No.1, pp.234.

Wintoki, M.B., Linck, J.S. and Netter, J.M. (2012), "Endogeneity and the dynamics of internal corporate governance”, Journal of Financial Economics, Vol. 105 No. 3, pp.581-606.

Zhang, J., Jiang, C., Qu, B., and Wang, P. (2013), "Market concentration, risk-taking, and bank performance: Evidence from emerging economies", International Review of Financial Analysis, Vol. 30, pp.149-157

Zheng, C., Moudud-Ul-Huq, S., Rahman, M.M. and Ashraf, B.N. (2017), "Does the ownership structure matter for banks' capital regulation and risk-taking behaviour? Empirical evidence from a developing country", Research in International Business and Finance, Vol. 42, pp.404421. 
Table 1 Definitions of the variables

\begin{tabular}{|c|c|c|c|c|c|}
\hline Variables & Measurement & Definition & Type & Exp.Sign & Source \\
\hline \multicolumn{6}{|c|}{ Dependent Variable: Credit Risk (CR) } \\
\hline $\begin{array}{l}\text { Non-Performing Loan } \\
\text { Ratio (NPLR) }\end{array}$ & $\begin{array}{l}\text { NPLR= non-performing loans /total loans (Berger et } \\
\text { al., 2009; Ghosh 2015) }\end{array}$ & $\begin{array}{l}\text { An index is measured by the response } \\
\text { of credit loss, reflecting a deterioration } \\
\text { of banks' balance sheets and asset } \\
\text { quality. }\end{array}$ & Bank specific & + & $\begin{array}{l}\text { Bank } \\
\text { scope }\end{array}$ \\
\hline $\begin{array}{l}\text { Loan Loss Provision } \\
\text { Ratio (LLPR) }\end{array}$ & $\begin{array}{l}\text { Ratio of loan loss provisions to net interest revenue } \\
\text { (LLPR = Loan Loss Provision (LLP) / Net Interest } \\
\text { Revenue (NIR)) (Ghosh, 2015; Nguyen and Boateng, } \\
\text { 2015; Hauner, 2008; Merton, 1974; Black and } \\
\text { Scholes, 1973; Lee and Chih, 2013) }\end{array}$ & $\begin{array}{l}\text { An index is measured credit quality by } \\
\text { using the provision to decrease loan } \\
\text { loss and lease losses-to-total loans }\end{array}$ & Bank specific & + & $\begin{array}{l}\text { Bank } \\
\text { scope }\end{array}$ \\
\hline \multicolumn{6}{|c|}{ Independent Variables: Bank Type (Type-Specific Variables) } \\
\hline $\begin{array}{l}\text { The state-owned share } \\
\text { proportion of government } \\
\text { ownership of banks } \\
\text { (GOVBANK) }\end{array}$ & $\begin{array}{l}\text { Government ownership of banks (GOBs) is defined as banks } \\
\text { where more than } 50 \text { percent of shares are owned by the } \\
\text { government (La Porta et al., 2002; Luo and Ying, 2014; } \\
\text { Dong et al., 2014). }\end{array}$ & $\begin{array}{l}\text { An index variable that measures the } \\
\text { proportion of shares held by the } \\
\text { government. }\end{array}$ & Bank specific & $-/+$ & $\begin{array}{l}\text { Bank } \\
\text { scope }\end{array}$ \\
\hline $\begin{array}{l}\text { The privately owned } \\
\text { share proportion of } \\
\text { private ownership of } \\
\text { banks (PRIBANK) }\end{array}$ & $\begin{array}{l}\text { Private ownership of banks (POBs) is defined as banks } \\
\text { where more than } 50 \text { percent of shares are owned by the } \\
\text { private firms (La Porta et al., 2002; Luo and Ying, 2014; } \\
\text { Dong et al., 2014). }\end{array}$ & $\begin{array}{l}\text { An index variable that measures the } \\
\text { proportion of shares held by individual and } \\
\text { private firms. }\end{array}$ & Bank specific & $-/+$ & $\begin{array}{l}\text { Bank } \\
\text { scope }\end{array}$ \\
\hline $\begin{array}{l}\text { Herfindahl-Hirschman } \\
\text { Index (HHI) }\end{array}$ & $\begin{array}{l}\text { Herfindahl-Hirschman Index (HHI) is a commonly accepted } \\
\text { measure of market concentration which we have measured as } \\
\text { the sum of the squared ownership shares of the top five } \\
\text { shareholders of the bank (Dong et al., 2014; Demsetz and } \\
\text { Lehn, 1985; Hou et al., 2013). }\end{array}$ & $\begin{array}{l}\text { An index variable that measures a market } \\
\text { concentration by testing the percentage of } \\
\text { the allocated shares of top five } \\
\text { shareholders to a total number of shares. }\end{array}$ & Bank specific & $+/-$ & $\begin{array}{l}\text { Bank } \\
\text { scope }\end{array}$ \\
\hline \multicolumn{6}{|c|}{ Control Variables: Panel A Macroeconomic factors } \\
\hline $\begin{array}{l}\text { CEO Total } \\
\text { Compensation } \\
\text { (CEO_TC) }\end{array}$ & $\begin{array}{l}\text { Log of CEO compensation (Acrey et al., 2011; } \\
\text { Borisova et al., 2012; Luo and Ying, 2014; Coles et } \\
\text { al., 2008; Griffith et al., 2002) }\end{array}$ & $\begin{array}{l}\text { An index variable that expresses the } \\
\text { amount of real CEO total } \\
\text { compensation (e.g. salary, stock return, } \\
\text { and equity) }\end{array}$ & Bank specific & - & $\begin{array}{l}\text { Bank } \\
\text { scope }\end{array}$ \\
\hline $\begin{array}{l}\text { GDP Growth Rate } \\
\text { (GDPR) }\end{array}$ & $\begin{array}{l}\text { GDP growth of China that is measured by the natural } \\
\text { logarithm of the annual Gross Domestic Products } \\
\text { growth (International Monetary Fund (IMF); De } \\
\text { Bondt, 1999; Nguyen and Boateng, 2013; 2015; } \\
\text { Ghosh, 2015; Fosu, 2014) }\end{array}$ & $\begin{array}{l}\text { An index is captured by the credit } \\
\text { demand effect and control for the } \\
\text { balance sheet channel effect where the } \\
\text { fall in the borrowers' net worth leads } \\
\text { to the decrease in bank credit supply. }\end{array}$ & Macroeconomic & - & NBSC \\
\hline
\end{tabular}




\begin{tabular}{|c|c|c|c|c|c|}
\hline $\begin{array}{l}\text { Unemployed Rate } \\
\text { (UNEMP) }\end{array}$ & $\begin{array}{l}\text { Unemployed-to-labor force (National Bureau of } \\
\text { Statistics of China(NBSC) (Fu and Heffernan, 2009; } \\
\text { Ghosh, 2015; Fosu, 2014) }\end{array}$ & $\begin{array}{l}\text { An index shows that its value } \\
\text { measures the ability of profitability } \\
\text { within a bank }\end{array}$ & Macroeconomic & + & NBSC \\
\hline Inflation Rate (INFR) & $\begin{array}{l}\text { Inflation is measured by the natural logarithm of } \\
\text { annual CPI(National Bureau of Statistics of } \\
\text { China(NBSC) (Fu and Heffernan, 2009; Ghosh, 2015; } \\
\text { Barth et al., 2009) }\end{array}$ & $\begin{array}{l}\text { An index refers as the level of default } \\
\text { rates within a bank }\end{array}$ & Macroeconomic & - & NBSC \\
\hline \multicolumn{6}{|c|}{ Panel B Bank characteristic index } \\
\hline Bank Size (SIZE) & $\begin{array}{l}\mathrm{BS}_{\mathrm{it}}=\log \mathrm{A}_{\mathrm{it}}-\left(\sum_{\mathrm{i}=1}{ }^{\mathrm{N}} \log \mathrm{A}_{\mathrm{it}} / \mathrm{N}_{\mathrm{t}}\right) \\
\text { Logarithm of the total assets (Gambacorta, 2005; } \\
\text { Nguyen et al., 2015; Ghosh, 2015) }\end{array}$ & $\begin{array}{l}\text { An index is reflected a bank's total } \\
\text { asset that resorts to the range of } \\
\text { excessive risk taking. }\end{array}$ & Bank specific & + & CSMAR \\
\hline $\begin{array}{l}\text { Bank Leverage Ratio } \\
\text { (LEVR) }\end{array}$ & $\begin{array}{l}\text { BLR=Equity/Liability (The World Bank Group; } \\
\text { Nguyen et al., 2015; Nguyen and Boateng, 2013; } \\
\text { 2015; D’Hulster, 2009) }\end{array}$ & $\begin{array}{l}\text { An index denotes its capital as } \\
\text { proportion of total adjusted assets in a } \\
\text { bank }\end{array}$ & Bank specific & + & CSMAR \\
\hline
\end{tabular}


Table 2 Summary statistics

\begin{tabular}{|c|c|c|c|c|c|c|}
\hline Variable & $\mathbf{N}$ & Mean & Std. Dev & Min & Max & Median \\
\hline NPLR(\%) & 1194 & 2.3541 & 5.1957 & 0.01 & 99.3 & 1.34 \\
\hline $\operatorname{LLPR}(\%)$ & 1194 & 0.7206 & 7.5390 & -8.378 & 192.6 & 0.0085 \\
\hline HHI & 1194 & 0.1027 & 0.1517 & 0.02655 & 1 & 0.0557 \\
\hline GOVBANK(\%) & 301 & 0.7353 & 0.1513 & 0.5024 & 1 & 0.7206 \\
\hline PRIBANK(\%) & 893 & 0.1879 & 0.1351 & 0 & 0.4993 & 0.175 \\
\hline GDPR(\%) & 1194 & 8.9141 & 2.2229 & 6.6 & 14.2 & 7.75 \\
\hline UNEMP(\%) & 1194 & 4.0790 & 0.1182 & 3.8 & 4.3 & 4.1 \\
\hline INFR(\%) & 1194 & 2.5844 & 1.8869 & -0.7 & 5.9 & 2.6 \\
\hline $\operatorname{LEVR}(\%)$ & 1194 & 6.4565 & 3.6859 & -20.794 & 45.66 & 6.23 \\
\hline SIZE(\%) & 1194 & 11.5950 & 2.4663 & 1.8825 & 25.6136 & 11.3007 \\
\hline
\end{tabular}

Note: This table presents that descriptive statistics for the data. The sample comprises 88 banks in China and 1194 observations during the period of 2003-2018. The Nonperforming Loan Ratio (NPLR) is the proportion of non-performing loans to total loans; Loan Loss Provision Ratio (LLPR) is the proportion of loan loss provision to net interest revenue (NIR). Explaining variables and control variables are indicators capturing the quality governance defined in detail in Subsection 6.3.2 and 6.3.3. GOVBANK is the state-owned share proportion of government-controlled banks which is more than $50 \%$. PRIBANK is privately owned banks which is more than $50 \%$. Growth GDP (GDPR); Unemployment (UNEMP); Inflation (INFR) and Leverage (LEVR). 
Table 3 Correlation matrix and variance inflation factor (VIF) coefficients

\begin{tabular}{|c|c|c|c|c|c|c|c|c|c|c|c|}
\hline & 120 & 2 & 3 & 4 & 5 & 6 & 7 & 8 & 9 & 10 & VIF \\
\hline 1.NPLR & 1.000 & & & & & & & & & & 1.09 \\
\hline 2.LLPR & -0.023 & 1.000 & & & & & & & & & 1.28 \\
\hline 3.GOVBANK & $0.234 * * *$ & $-0.159 * * *$ & 1.000 & & & & & & & & 1.14 \\
\hline 4.PRIBANK & 0.008 & $-0.082 * *$ & 0.000 & 1.000 & & & & & & & 1.12 \\
\hline 5.HHI & 0.019 & 0.001 & $0.221 * * *$ & $-0.238 * * *$ & 1.000 & & & & & & 1.19 \\
\hline 6.GDPR & $0.135 * * *$ & -0.012 & 0.104 & 0.028 & -0.018 & 1.000 & & & & & 1.23 \\
\hline 7.UNEMP & $0.113 * * *$ & 0.027 & 0.040 & 0.007 & 0.004 & $0.309 * * *$ & 1.000 & & & & 1.14 \\
\hline 8.INFR & -0.014 & -0.006 & -0.067 & -0.011 & -0.027 & $0.370 * * *$ & $0.141 * * *$ & 1.000 & & & 1.18 \\
\hline 9.LEVR & $-0.149 * * *$ & -0.018 & $-0.267 * * *$ & $-0.098 * *$ & $-0.088 * *$ & $-0.055^{*}$ & -0.010 & $0.056^{*}$ & 1.000 & & 1.22 \\
\hline 10.SIZE & -0.012 & $-0.265 * * *$ & 0.088 & -0.010 & $0.275^{* * *}$ & $-0.182 * * *$ & -0.045 & $0.064 *$ & $-0.065 *$ & 1.000 & 1.39 \\
\hline
\end{tabular}

Note: $*$ denotes $\mathrm{p}<0.05, * *$ denotes $\mathrm{p}<0.01, * * *$ denotes $\mathrm{p}<0.001$. VIF(Variance Inflation Factor, VIF): the degree of collinearity in explanatory variable. The result presents how much of the inflation of the standard error could be produced by multicollinearitys. Tolerance(Tol): it shows how much collinearity that a regression analysis can tolerate. In fact, the corresponding VIF is simply $1 /$ tolerance. On average, both the tolerance and VIF are 1 . If a variable is very closely related to another variable(s), the tolerance goes to 0 , and the variance inflation gets very large. A tolerance value lower than 0.1 is comparable to a VIF of 10 . It means that the variable could be considered as a linear combination of other independent variables. 
Table 4 System GMM results

\begin{tabular}{|c|c|c|c|c|c|c|c|c|}
\hline & NPLR & LLPR & NPLR & LLPR & NPLR & LLPR & NPLR & LLPR \\
\hline Exp var & Model 1 & Model 2 & Model 3 & Model 4 & Model 5 & Model 6 & Model 7 & Model 8 \\
\hline $\mathrm{NPLR}_{\mathrm{t}-1}$ & $\begin{array}{l}0.0372 * * * \\
(30.77)\end{array}$ & & $\begin{array}{l}0.485 * * * \\
(1111.79)\end{array}$ & & & & & \\
\hline $\operatorname{LLPR}_{\mathrm{t}-1}$ & & $\begin{array}{l}0.830 * * * \\
(182.71)\end{array}$ & & $\begin{array}{l}0.0070 * * * \\
(18.52)\end{array}$ & & & & \\
\hline GOVBANK & $\begin{array}{l}4.191 \\
(0.54)\end{array}$ & $\begin{array}{l}9.690 * * * \\
(16.06)\end{array}$ & & & & & & \\
\hline PRIBANK & & & $\begin{array}{l}4.864 * * * \\
(15.79)\end{array}$ & $\begin{array}{l}26.24 * * * \\
(5.62)\end{array}$ & & & & \\
\hline GOV_HHI & & & & & $\begin{array}{l}-12.13 * * * \\
(-4.86)\end{array}$ & $\begin{array}{l}-8.321 * * * \\
(-14.61)\end{array}$ & & \\
\hline PRI_HHI & & & & & & & $\begin{array}{l}189.9 * * * \\
(9.59)\end{array}$ & $\begin{array}{l}880.5 * * * \\
(283.24)\end{array}$ \\
\hline GDPR & $\begin{array}{l}-1.546 \\
(-0.68)\end{array}$ & $\begin{array}{l}-6.546 \\
(-1.61)\end{array}$ & $\begin{array}{l}4.197 * * * \\
(32.78)\end{array}$ & $\begin{array}{l}0.199 * * * \\
(22.66)\end{array}$ & $\begin{array}{l}0.0208 \\
(0.20)\end{array}$ & $\begin{array}{l}41.84 * * \\
(2.18)\end{array}$ & $\begin{array}{l}0.750^{* * * *} \\
(3.51)\end{array}$ & $\begin{array}{l}0.419 * * * \\
(2.51)\end{array}$ \\
\hline UNEMPR & $\begin{array}{l}0.170 \\
(0.01)\end{array}$ & $\begin{array}{l}-34.90 \\
(-0.92)\end{array}$ & $\begin{array}{l}46.56^{* * * *} \\
(38.08)\end{array}$ & $\begin{array}{l}1.278^{* * * *} \\
(48.06)\end{array}$ & $\begin{array}{l}-0.104 \\
(-0.11)\end{array}$ & $\begin{array}{l}172.5^{*} \\
(1.66)\end{array}$ & $\begin{array}{l}11.51^{* * * *} \\
(3.04)\end{array}$ & $\begin{array}{l}41.22 * * * \\
(25.56)\end{array}$ \\
\hline INFR & $\begin{array}{l}-928 * * * \\
(-2.34)\end{array}$ & $\begin{array}{l}-0.369 \\
(-0.54)\end{array}$ & $\begin{array}{l}-0.422 * * * \\
(-21.92)\end{array}$ & $\begin{array}{l}-0.293 * * * \\
(-200.17)\end{array}$ & $\begin{array}{l}-0.274 * * * \\
(-9.82)\end{array}$ & $\begin{array}{l}2.935 \\
(1.11)\end{array}$ & $\begin{array}{l}-0.0490 \\
(-1.35)\end{array}$ & $\begin{array}{l}-0.104 * * * \\
(-13.51)\end{array}$ \\
\hline LEVR & $\begin{array}{l}0.654 \\
(1.40)\end{array}$ & $\begin{array}{l}0.199 \\
(0.19)\end{array}$ & $\begin{array}{l}-1.425 * * * \\
(10.06)\end{array}$ & $\begin{array}{l}-0.0792 * * * \\
(-21.00)\end{array}$ & $\begin{array}{l}-0.218^{* *} \\
(2.20)\end{array}$ & $\begin{array}{l}12.58 \\
(1.45)\end{array}$ & $\begin{array}{l}-0.730 * * * \\
(-4.73)\end{array}$ & $\begin{array}{l}-4.607 * * * \\
(-144.59)\end{array}$ \\
\hline SIZE & $\begin{array}{l}-4.358 \\
(-0.81)\end{array}$ & $\begin{array}{l}1.594 \\
(0.21)\end{array}$ & $\begin{array}{l}-2.508 * * * \\
(-10.62)\end{array}$ & $\begin{array}{l}-0.984 * * * \\
(-15.28)\end{array}$ & $\begin{array}{l}-2.856 * * * \\
(-3.42)\end{array}$ & $\begin{array}{l}174.3^{* * * *} \\
(3.28)\end{array}$ & $\begin{array}{l}-7.021 * * * \\
(-5.55)\end{array}$ & $\begin{array}{l}-11.79 * * * \\
(-50.29)\end{array}$ \\
\hline _cons & $\begin{array}{l}-64.46^{* * *} \\
(-13.49)\end{array}$ & $\begin{array}{l}1.646^{* * *} \\
(3.59)\end{array}$ & $\begin{array}{l}-69.44 * * * \\
(-40.87)\end{array}$ & $\begin{array}{l}0.909 * * * \\
(6.00)\end{array}$ & $\begin{array}{l}-64.46^{* * *} \\
(-13.49)\end{array}$ & $\begin{array}{l}1.646^{* * * *} \\
(3.59)\end{array}$ & $\begin{array}{l}6.361 \\
(0.82) \\
\end{array}$ & $\begin{array}{l}66.10 * * * \\
(22.12)\end{array}$ \\
\hline N/N_g & $160 / 29$ & $160 / 29$ & $450 / 72$ & $450 / 72$ & $479 / 76$ & $481 / 76$ & $450 / 72$ & $450 / 72$ \\
\hline Artests & 2 & 2 & 2 & 2 & 2 & 2 & 2 & 2 \\
\hline $\mathrm{AR}(1)$ & -1.126 & -0.999 & -1.086 & -1.114 & -1.126 & -0.516 & -1.077 & -0.188 \\
\hline $\mathrm{AR}(2)$ & -0.879 & -0.261 & -0.679 & 1.004 & 0.879 & 0.313 & -0.193 & -1.189 \\
\hline P-value & 0.0000 & 0.0000 & 0.0000 & 0.0000 & 0.0000 & 0.0000 & 0.0000 & 0.0000 \\
\hline Sargan & $20.20 * * *$ & $24.27 * * *$ & $22.70 * * *$ & $24.35 * * *$ & $20.20 * * *$ & $24.27 * * *$ & $48.50 * * *$ & $45.79 * * *$ \\
\hline
\end{tabular}

Note: $\mathrm{t}$ statistics in parentheses, ${ }^{*} \mathrm{p}<0.05, * * \mathrm{p}<0.01, * * * \mathrm{p}<0.001$. The table reports empirical results from estimating Eq.(1), (2). In addition, column $2,3,4$ and 5 reports the results obtained from two dependent variables with clustering at the bank level, respectively. The two-step system GMM approach is reported in parentheses and based on Windmeijer-corrected standard errors. Year dummies and ownership type dummies are unreported. The Arellano-Bond test is for zero autocorrelation in first-differenced errors and first-order serial correlation, but no second-order serial correlation in the residuals (Arelano and Bond 1991). The Sargan test justifies the validity of the overidentifying restrictions. 
Table 5 System GMM results (Interaction of ownership structure and ownership concentration)

\begin{tabular}{|c|c|c|c|c|}
\hline & NPLR & LLPR & NPLR & LLPR \\
\hline Exp var & Model 1 & Model 2 & Model 3 & Model 4 \\
\hline NPLRt-1 & $\begin{array}{l}0.0404 * * * \\
(6.75)\end{array}$ & & $\begin{array}{l}0.499 * * * \\
(770.07)\end{array}$ & \\
\hline LLPRt-1 & & $\begin{array}{l}0.828 * * * \\
(1411.62)\end{array}$ & & $\begin{array}{l}0.00343 * * * \\
(9.88)\end{array}$ \\
\hline GOVBANK & $\begin{array}{l}0.289 \\
(0.15)\end{array}$ & $\begin{array}{l}1.478 * * * \\
(704.96)\end{array}$ & & \\
\hline PRIBANK & & & $\begin{array}{l}12.72 * * * \\
(5.78)\end{array}$ & $\begin{array}{l}4.569 * * * \\
(11.50)\end{array}$ \\
\hline GOV_HHI & $\begin{array}{l}-2.270^{* * *} \\
(-6.73)\end{array}$ & $\begin{array}{l}-2.296 * * * \\
(-7.50)\end{array}$ & & \\
\hline PRI_HHI & & & $\begin{array}{l}63.54 * * * \\
(8.07)\end{array}$ & $\begin{array}{l}304.9 * * * \\
(96.35)\end{array}$ \\
\hline HHI*GOVBANK & $\begin{array}{l}-2.397 * * \\
(-2.34)\end{array}$ & $\begin{array}{l}-2.661 * * * \\
(-213.20)\end{array}$ & & \\
\hline HHI*PRIBANK & & & $\begin{array}{l}64.09^{* * *} \\
(16.14)\end{array}$ & $\begin{array}{l}943.1^{* * *} \\
(579.50)\end{array}$ \\
\hline GDPR & $\begin{array}{l}3.920 * * * \\
(10.95)\end{array}$ & $\begin{array}{l}0.175 * * * \\
(425.83)\end{array}$ & $\begin{array}{l}0.540 * * \\
(2.34)\end{array}$ & $\begin{array}{l}1.875^{* * *} \\
(12.12)\end{array}$ \\
\hline UNEMPR & $\begin{array}{l}41.56^{* * * *} \\
(14.19)\end{array}$ & $\begin{array}{l}1.277^{* * *} \\
(48.05)\end{array}$ & $\begin{array}{l}9.911 \text { *** } \\
(3.31)\end{array}$ & $\begin{array}{l}53.47 * * * \\
(27.51)\end{array}$ \\
\hline INFR & $\begin{array}{l}-0.438 * * * \\
(-23.85)\end{array}$ & $\begin{array}{l}-0.256^{* * *} \\
(-763.10)\end{array}$ & $\begin{array}{l}-0.137 * * * \\
(-4.34)\end{array}$ & $\begin{array}{l}0.0722 * * * \\
(6.18)\end{array}$ \\
\hline LEVR & $\begin{array}{l}-1.417 * * * \\
(-8.31)\end{array}$ & $\begin{array}{l}-0.0526 * * * \\
(-321.79)\end{array}$ & $\begin{array}{l}-0.741 * * * \\
(-5.49)\end{array}$ & $\begin{array}{l}-4.616^{* * *} \\
(-84.89)\end{array}$ \\
\hline SIZE & $\begin{array}{l}-1.337 * * * \\
(-2.80)\end{array}$ & $\begin{array}{l}-0.256^{* * *} \\
(-372.00)\end{array}$ & $\begin{array}{l}-4.675^{* * *} \\
(-4.13)\end{array}$ & $\begin{array}{l}-12.29 * * * \\
(-55.00)\end{array}$ \\
\hline _cons & $\begin{array}{l}-64.86^{* * * *} \\
(-27.99)\end{array}$ & $\begin{array}{l}0.910 * * * \\
(6.00)\end{array}$ & $\begin{array}{l}-2.465 \\
(-0.37)\end{array}$ & $\begin{array}{l}92.16^{* * *} \\
(27.19)\end{array}$ \\
\hline N/N_g & $160 / 29$ & $160 / 29$ & $481 / 76$ & $481 / 76$ \\
\hline Artests & 2 & 2 & 2 & 2 \\
\hline $\mathrm{AR}(1)$ & -1.223 & -1.114 & -1.082 & -0.442 \\
\hline AR(2) & -0.865 & 1.004 & -0.261 & -1.150 \\
\hline $\begin{array}{l}\text { P-value } \\
\text { Sargan }\end{array}$ & $\begin{array}{l}0.0000 \\
20.70 * * *\end{array}$ & $\begin{array}{l}0.0000 \\
24.36^{* * *} \\
\end{array}$ & $\begin{array}{l}0.0000 \\
34.64 * * *\end{array}$ & $\begin{array}{l}0.0000 \\
47.98 * * *\end{array}$ \\
\hline
\end{tabular}

Note: $\mathrm{t}$ statistics in parentheses, ${ }^{*} \mathrm{p}<0.05, * * \mathrm{p}<0.01, * * * \mathrm{p}<0.001$. The table reports empirical results from estimating Eq.(1), (2). In addition, column $2,3,4$ and 5 reports the results obtained from two dependent variables with clustering at the bank level, respectively. The T-statistics are reported in the parenthesis. Year dummies and ownership type dummies are unreported. The Arellano-Bond test is for zero autocorrelation in first-differenced errors and first-order serial correlation, but no second-order serial correlation in the residuals (Arelano and Bond 1991). The Sargan test justifies the validity of the overidentifying restrictions. 
Title of the paper: Impact of Ownership Structure and Ownership Concentration on Credit Risk of Chinese Commercial Banks 